\title{
Joseph Story on Capital Punishment
}

\author{
Edited by John C. Hogan*
}

[Editor's note: this article, originally entitled "Death Punishment," first appeared as an anonymous article in the first edition of the Encyclopedia Americana (18291833). Extensive rèsearch as to the circumstances of authorship of this, and other anonymous articles in the same edition, has been done and reported elsewhere by Mr. Hogan. See Hogan, Joseph Story's Anonymous Law Article, 52 Mrch. L. REv. 869 (1954). In view of the current controversy in California concerning capital punishment, it is the opinion of the California Law Review that the views on this subject of Mr. Story, first written more than one hundred years ago and reappearing here for the first time, are of considerable current interest.]

\section{PUNISHMENT OF DEATH ${ }^{1}$}

The questions most commonly discussed by philosophers and jurists under this head are: (1) as to the right of governments to inflict the punishment of death; (2) as to the expediency of such punishment; (3) as to the crimes to which, if any, it may be most properly confined and limited; (4) as to the manner in which it should be inflicted. A few words will be said on each of these points.

1. As to the right of inflicting the pumishment of death. This has been doubted by some distinguished persons; and the doubt is often the accompaniment of a highly cultivated mind, inclined to the indulgence of a romantic sensibility, and believing in human perfectibility. The right of society to punish offences against its safety and good order will scarcely be doubted by any considerate person. In a state of nature, individuals have a right to guard themselves from injury, and to repel all aggressions by a force or precaution adequate to the object. This results from the right of self-preservation. If a person attempts to take away my life, I have, doubtless, a right to protect myself against the attempt by all reasonable means. If I cannot secure myself but by taking the life of the assailant, I have a right to take it. It would otherwise follow, that I must submit to a wrong, and lose my life, rather than preserve it by the means adequate to nraintain it. It cannot, then, be denied that, in a state of nature, men may repel force by force, and may even justly take away life, if necessary to preserve their own.

When men enter society, the right to protect themselves from injury and to redress wrongs is transferred, generally, from the individuals to the community. We say that it is generally so, because it must be obvious that, in many cases, the natural right of self-defense must remain. If a robber

* Research Editor, the RAND Corporation, Santa Monica, California.

${ }^{1}$ From IV Encyclopedia Amertcana 140-145 (1st ed. 1830). 
attacks one on the highway, or attempts to murder him, it is clear that he has a right to repel the assault, and to take the life of the assailant, if necessary for his safety; since society, in such a case, could not afford lim any adequate and prompt redress. The necessity of instant relief, and of instant application of force, justifies the act, and is recognized in all civilized communities.

When the right of society is once admitted to punisl for offences, it seems difficult to assign any limits to the exercise of that right, short of what the exigencies of society require. If a state have a right to protect itself and its citizens in the enjoyment of its privileges and its peace, it must have a right to apply means adequate to this object. The object of human punishments is, or may be, three-fold: first, to reform the offender; secondly, to deter others from offending; and, lastly, to secure the safety of the commumity, by depriving the offender of the power of doing mischief. .

The first consideration rarely enters into human legislation, because of the inadequacy of our means to produce great inoral results by the infliction of pumshment. The two latter considerations enter largely into the theory and practice of legislation. Who is to be the judge, in such cases, as to what is the adequate punishment for any offense? Certainly, punishments ouglit not to be inflicted, which are utterly disproportionate to the offence, and beyond the exigencies of society. No government has a right to pumish cruelly and wantonly, and from mere revenge; but, still, the discretion must be vested somewhere, to say what shall be the degree of punishment to be assigned to a particular offence.

That discretion inust be, from its nature, justly a part of the legislative power, and to be exercised according to the actual state of society. It may, nay, it must be differently exercised in different ages, and in different countries; for the same punisliment which, in one age or country, may be sufficient to suppress an offence, or render it comparatively harmless, may, in another age or country, wholly fail of the effect. If mild punishments fail of effect, more severe inust be resorted to, if the offence be of a nature which affects society in its vital principles, or safety, or interests. The very frequency of a crime must often furmish a very strong ground for severe punishment, not only as it furnishes proof that the present punishment is insufficient to deter men from committing it, but from the increased necessity of protecting society against dangerous crimes.

But it is often said, that life is the gift of God, and therefore it camiot justly be taken away, either by the party himself, or another. If he cannot take it away, he cannot confer that power on others. But the fallacy of this argnment is obvious. Life is no more the gift of God than other personal endowments or rights. A inan lias, by the gift of God, a riglit to personal liberty and locomotion, as well as to life; to eat and drink and breathe at 
large, as well as to exist; yet no one doubts that, by way of punishment, he inay be confined in a solitary cell; that he may be perpetually imprisoned or deprived of free air, or compelled to live on bread and water. In short, no one cloubts that he may be restrained in the exercise of any privileges or natural rights short of taking his life.

Yet the reasoning, if worth anything, extends to all these cases in an equal degree. If, by his crimes, a man may justly forfeit his personal rights, why not his life? But we have seen that it is not true, even in a state of nature, that a man's life may not be taken away by another, if the necessity of the case requires it. Why, then, may not society do the same, if its own safety requires it? Is the safety of one person more important than the safety of the whole community?

Then, again, as to a man's inability to confer on others a right which he does not himself possess. Suppose it is so; the consequence which is deduced from this does not, in fact, arise. Blackstone, indeed, in his Commentaries (Vol. IV, p. 8), seems to deduce the right of society to punish capital offences, in certain cases (that is, in cases of mala prohibita, and in mala in se), from the consent of the offenders. The marquis Beccaria, on the other hand, denies that any such consent can confer the right, and therefore objects to its existence.

But the notion of consent is, in nearly all cases, a mere theory, having no foundation in fact. If a foreigner comes into a country, and commits a crime at his first entrance, it is a very forced construction to say that he consents to be bound by its laws. If a pirate commits piracy, it is almost absurd to say that he consents to the right of all nations to pumsh him for it. The true and rational ground on which the right rests, is not the consent of the offender, but the right of every society to protect its own peace, and interests, and property, and institutions, and the utter want of any right, in other persons, to disturb, or destroy, or subtract them.

The right flows, not from consent, but from the legitimate institution of society. If men have a right to form a society for mutual benefit and security, they have a right to punish other persons who would overthrow it. There are many cases where a state authorizes life to be taken away, the lawfulness of which is not doubted. No reasonable man doubts the right of a nation, in a just war, especially of self-defence, to repel force by force, and to take away the lives of its enemies. And this right is not confined to repelling present force, but it extends to precautionary measures, which are necessary for the ultimate safety of the nation. In such a war, a nation may justly insist upon the sacrifice of the lives of its own citizens, however innocent, for the purpose of ensuring its own safety. Accordingly, we find that all nations enroll militia and employ troops for war, and require them to hazard their lives for the preservation of the state. In these cases, life is 
freely sacrificed by the nation; and the laws enacted for such purposes are deemed just exercises of power. If so, why may not life be taken away by way of punishment, if the safety of society requires it? If a nation may authorize, in war, the destruction of thousands, why may it not authorize the destruction of a single life, if self-preservation require it?

The mistake, however, is in supposing that life cannot be taken away without the consent of the party. If the foregomg reasoning is correct, such consent is neither supposed nor necessary. In truth, the supposition of an original compact between all the persons who are subject to the regulations of a society, by their own free consent, as the necessary and proper basis on which all the rights of such society depend, is, at best, a gratuitous supposition; and it sonietimes leads to very incorrect results. It may be added, that the Scriptures nost clearly recognize and justify the infliction of capital punishment in certain cases.

2. As to the expediency of capital punishment. This opens a wide field for discussion. Some able men, who do not doubt the right, do still deny the expediency of inflicting it. It may be admitted, that a wise legislature ought to be slow in affixing such a punishnient to any but very enormous and dangerous crinies. The frequency of a crime is not, of itself, a sufficient reason for resorting to such punishnient. It should be a crime of great atrocity and danger to society, and which cannot otherwise be effectually guarded against.

In affixing punishments to any offence, we should consider what are the objects and ends of punishment. It is clear that capital punishment can have no effect to reforn the offender himself. It may have, and ordinarily does have, the effect to deter others fron conmitting a like offence; but, still, human experience shows that even this punishment, when inflicted for small offences, which are easily perpetrated, and to which there is great teniptation, does not always operate as an effectual terror. Men sonetimes are hardened by the frequent spectacles of capital punishments, and grow indifferent to them. Familiarity deprives them of their horror. The bloodiest codes are not those which have most effectually suppressed offences. Besides, public opimion has great weight in producing the acquittal or condemnation of offenders. If a punishnent be grossly disproportionate to the offence, if it shock hunian feelings, there arises, insensibly, a sympathy for the victim, and a desire to screen hin from punishment; so that, as far as certainty of punishment operates to deter from crimes, the object of the legislature is often thus defeated.

It may be added, that a reasonable doubt may fairly be entertained whether any society can lawfully exercise the power of punishing beyond what the just exigencies of that society require. On the other hand, a total abolition of capital punishments would, in some cases at least, expose so- 
ciety to the chances of deep and vital injuries. A man who has committed murder deliberately, has proved himself unfit for society, and regardless of all the duties which belong to it. In his case, the lex talionis can hardly be deemed unjust.

The safety of society is most effectually guarded by cutting him off from the power of doing further mischief. If his life be not taken away, the only other means left are, confinement for life, or transportation and exile for hife. Neither of these is a perfect security against the commission of other crimes, and may not always be within the power of a nation without great inconvenience and great expense to itself. It is true that the latter punishments leave open the chance of reform to the offender, which is, indeed, but too often a mere delusion; but, on the other hand, they greatly diminish the influence of another salutary principle, the deterring of others from committing like crimes.

It seems to us, therefore, that it is difficult to maintain the proposition that capital punishments are, at all times and under all circumstances, inexpedient. It may rather be affirmed that, in some cases, they are absolutely indispensable to the safety and good order of society. We should incline to say that, as a general rule, every nation, in its legislation on this subject, must be governed very much by the manners, customs, habits of thinling, and state of opinion, among the people upon whom it is to operate. In a rude and barbarous state of society, summary and almost vindictive punishments seem more necessary than in a highly polished and civilized state of society.

3. As to the crimes to which capital punishments may, most properly, be limited. From what has been already said, this must depend upon the particular circumstances of every age and nation; and much must be left to the exercise of a sound discretion on the part of the legislature. As a general rule, humanity forbids such punishments to be applied to any but crimes of very great enormity, and danger to individuals or the state. If any crimes can be effectually suppressed by moderate means, these ought, certainly, to be first resorted to.

The experience, however, of most nations, if we may judge from the nature and extent of their criminal legislation, seems to disprove the opinion so often indulged by philanthropists, that moderate punishments are sufficient to suppress crimes, and that capital punishments are rarely necessary. The codes of most civilized nations abound with capital punishments. That of Great Britain, a nation in which the public legislation has a deep infusion of popular opinion, is thought to be uncommonly sanguinary. Blackstone, in his Commentaries (Vol. IV, p. 18), admits that, in his time, not less than one hundred and sixty crimes were, by the English law, punishable with death. In the code of the Umited States, only nine crimes are so punishable, viz., treason, murder, arson, rape, robbery of the mail, fraudu- 
lent casting away ships, rescue of criminals capitally convicted during execution, and piracy, one species of which is the African slave-trade. In the codes of the several states of the Union, still fewer crimes are generally punishable with death.

It remains yet to be proved, whether the general mildness of our penal code has afforded us any greater security against crimes than exists in other nations. Hitherto, the temptations to commit them have been less here, than in other countries less abundantly and cheaply supplied with the necessaries of life. It is still a question, fit to exercise the solicitude and ingenuity of our statesmen and philanthropists, whether we can safely carry on so mild a system in a more corrupt and dense state of society. If we can, it must be by a very sparing use of the power of pardoming; so that the certainty of absolute, unmitigated punishment shall follow upon the offence.

Beccaria, with his characteristic humanity and sagacity, has strongly urged that the certainty of pumshment is more important to deter from crimes than the severity of it. At present, there is great danger that the pardoming power, in our free forms of government, will, in a great measure, overthrow this salutary principle. Its exercise, therefore, ought to be watched with the greatest jealousy and care, lest the abuse of it should lead to the introduction either of absolute' impumity for offences, or of more extensive capital punishments. It will probably be found, from the experience of nost nations, that capital pumshment ought not wholly to be dispensed with. On the other hand, it nuay be safely affirnied, that there is no positive necessity to apply it to a very large number of crimes. Treason, murder, arson, piracy, highway robbery, burglary, rape, and some other offences of great enormity, and of a kindred character, are not uncommonly pumished in this manner; but beyond these, it is extremely questionable whether there is any necessity or expediency of applying so great a severity. Still, however, as has been already intimated, much nust depend upon the opinion and character of the age, and the prevailing habits of the people, and upon the sound exercise of legislative discretion. What may be deemed uselessly severe in one age or country, may be positively required by the circumstances of another age or country.

4. As to the manner of inflicting the punishment of death. This has been different in different countries, and in different stages of civilization in the same countries. Barbarous nations are generally inclined to severe and vindictive pumishments, and, where they pumish with death, to aggravate it by prolonging the sufferings of the victim with ingenious devices in cruelty. And even in civilized countries, $m$ cases of a political nature, or of very great atrocity, the punishment has been sometimes inflicted with many horrible accompamiments. Tearing the criminal to pieces, piercing his brcast with a pointed pole, pinching to death with red-hot pincers, starving him to 
death, breaking his limbs upon the wheel, pressing him to death in a slow and lingering manner, burning him at the stake, crucifixion, sawing him to pieces, quartering him alive, exposing him to be torn to pieces by wild beasts, and other savage punishments, have been sometimes resorted to for the purposes of vengeance, or public exanple, or public terror. Compared with these, the infliction of death by drowning, by strangling, by poisoning, by bleeding, by beheading, by shooting, by hanging, is a moderate punishment.

In modern times, the public opinion is strongly disposed to discountenance the punishment of death by any but simple means; and the infliction of torture is almost universally reprobated. Even in governments where it is still countenanced by the laws, it is rarely resorted to; and the sentence is remitted, by the policy of the prince, beyond the simple infliction of death. In Prussia, where atrocious criminals are required, by the penal code, to be broken upon the wheel, the king always issues an order to the executioner to strangle the criminal (which is done by a small cord not easily seen) before his limbs are broken. So, in the same country, where larceny, attended with destruction of life, is pumished by burning alive, the fagots are so arranged as to form a kind of cell, in which the criminal is suffocated by the fumes of sulphur, or other means, before the flame can reach him. In England, in high treason, the criminal is sentenced to be drawn to the gallows, to be hanged by the neck, and cut down alive, to have his entrails taken out and burned while he is yet alive, to have his head cut off, and his body divided into four parts, and these to be at the king's disposal. But, generally, all the punishment is remitted by the crown, except the hanging and beheading; and when it is not, by connivance of the officers, the criminal is drawn on a hurdle to the place of execution, and is not disembowelled until actually dead. In other cases, the punishment is now simply by hanging, or, in the military and naval service, by shooting.

In France, formerly, the punishment of death was often inflicted by breaking the criminal on the wheel. (Damiens was torn to pieces by horses, after he had been tormented with red-hot pincers, and had suffered other horrid tortures.) The usual punishment now is beheading by the guillotine. In cases of parricide, the criminal is conducted, barefooted, and covered with a black veil, to the place of execution, where his right hand is cut off just before he is beheaded. In Austria, the general mode of punishment is by hanging. In Prussia, hanging is rarely inflicted; but the usual punishment is beheading with a heavy axe, the criminal's head being first tied to a block. In other German states, the uncertain mode of execution by the sword still exists. Sand was executed in this manner. It should be remarked, however, that, in Germany, hanging has always been deemed the most infamous sort of punishment; and the sentence has often been commuted for beheading by the sword, as a milder mode of pumishment. 
In the United States of America, hanging is the universal mode of capital punishment; and, indeed, the constitution of the United States contains a provision, declaring that "cruel and unusual punishments shall not be inflicted." In China, murderers are cut to pieces; robbers, not. In Russia, the punishment of death has been frequently inflicted by the knout. In Turkey, strangling, and sewing the criminal up in a bag, and throwing him into the sea, are common modes of punishment.

In the Roman code, many severe and cruel punishments were prescribed. During the favored times of the republic, niany of these were abolished or mitigated. But again, under the emperors, they were revived with full severity. In the ancient Grecian states, the modes of punishment were also severe, and often cruel. But the most general mode of punishment, in ordinary cases, seems, both in Greece and Rome, to have been by hanging.

Whether the ancient Greek mode of capital punishment, by taking poison at such hour as the condemned party should choose, has ever been adopted in any modern nation, we are unable to say. As far as we have been able to learn, it is not in use among any Christian people; and the idea of suicide connected with it would probably prevent any such nation from adopting it.

Whether executions ought to be in public or in private, has been a question much discussed, and upon which a great diversity of opinion exists among intelligent statesmen. On the one hand, it is said that public spectacles of this sort have a tendency to brutalize and harden the people, or to nuake them indifferent to the punishment; and the courage and firniness, with which the criminal often meets death, have a tendency to awaken feelings of sympathy, and even of admiration, and to take away nuch of the horror of the offence, as well as of the punishment. On the other hand, it is said that the great influence of punishment, in deterring others fronl the like offence, cannot be obtained in any other way. It is the only nieans to bring home to the mass of the people a salutary dread and warning; and it is a public adnionition of the certainty of punishment following upon crimes. It is also added, that all punishments ought to be subjected to the public scrutiny, so that it may be known that all the law requires, and no more, has been done. If punishments were inflicted in private, it could never be known whether they were justly and properly inflicted upon the persons condemned; or whether indeed, innocent persons might not beconie the victims.

In England, the court before which the trial is had, declares the sentence, and directs the execution of it; and its warrant is a sufficient authority to the proper officer to execute it. In the courts of the United States, there is a like authority; but in the laws of many of the states, there is a provision that the execution shall not take place except by a warrant from the gover- 
nor, or other executive authority. In cases of murder and other atrocious crimes, the punishment in England is usually inflicted at a very short interval after the sentence. In America, there is usually allowed a very considerable interval, varying from one month to six months.

In England and America, there lies no appeal from the verdict of a jury and the sentence of a court, in capital cases. In France, there may be a review of it in the court of cassation. (q.v.) In Germany, there is, in criminal as in civil cases, a right of appeal; hence, in that country, few innocent persons have suffered capitally simce the 16th century; and in England and America, the very fact that the verdict and sentence are final, produces great caution and dehberation in the administration of criminal justice, and a strong leaning towards the prisoner on trial.

Capital punishment cannot be inflicted, by the general humamity of the laws of modern nations, upon persons who are insane or who are pregnant, until the latter are delivered and the former become sane. It is said that Frederic the Great required all judgments of his courts, condemning persons to death, to be written on blue paper; thus he was constantly reminded of them as they lay on his table among other papers, from which they were readily distinguished. He usually took a long time to consider such cases, and thus set an excellent example to sovereigns of their duty. 